\title{
EKSIBISI DAUR ULANG SAMPAH ANORGANIK
}

\author{
Andy $^{1)}$, Lina Purnama ${ }^{2)}$ \\ 1) Program Studi S1 Arsitektur, Fakultas Teknik, Universitas Tarumanagara, andyabeng_1@yahoo.co.id \\ 2) Program Studi S1 Arsitektur, Fakultas Teknik, Universitas Tarumanagara, Ipurnama.112@gmail.com
}

\begin{abstract}
Abstrak
Metropolis atau di sebut sebagai ibukota yang fungsinya adalah sebagai kota industri dan perdagangan, dengan tingkat kepadatan yang tinggi (satu hingga tiga juta penduduk). Metropolis menjadi suatu tempat yang memiliki peran penting dalam mengatur perekonomian dan politik. Sementara itu untuk menggerakkan roda perekonomian metropolis salah satu caranya yaitu melalui pariwisata (2016 kontribusi total perjalanan dan turisme terhadap PDB dunia sebesar 7.613.3 juta USD dan semakin naik pada tahun 2017 sebesar 3.6\% dan diperkirakan akan terus naik) (World Travel \& Tourism Council, n.d.). Setelah melakukan pencarian data dengan melakukan survei di beberapa titik dan mengkaji literatur, maka digunakan teori architourism di metropolis untuk membantu mengembangkan perekonomian metropolis. Akan tetapi selain memiliki dampak positif, pariwisata juga memiliki dampak negatif terhadap metropolis yaitu banyaknya sampah yang di hasilkan oleh wisatawan (USA TODAY, 2018). Solusi yang dapat menyelesaikan permasalahan tersebut yaitu dengan dibuatnya sebuah ruang untuk mengedukasi masyarakat dan turis mengenai pentingnya menjaga lingkungan dari sampah, menunjukkan nilai guna dari sampah kemudian mengolah sampah-sampah tersebut menjadi sesuatu yang berguna, menjadikan hal tersebut sebagai tontonan maupun alat interaktif bagi turis sehingga mampu menarik perhatian turis tetapi juga dapat meringankan permasalahan sampah yang ada di kota metropolis. Solusi-solusi tersebut di padukan menjadi sebuah ruang ekshibisi daur ulang sampah anorganik yang dapat mengubah pola pikir turis-turis yang datang mengenai keburukan sampah dari suatu benda yang tidak bernilai menjadi memiliki nilai dan guna.
\end{abstract}

Kata kunci: Architourism; Edukasi; Metropolis; Pariwisata; Sampah

\begin{abstract}
Metropolis or referred as the Capital City that works as an industrial and trade city, with a high density (one to three million inhabitants). The metropolis becomes a place that has an important role in producing economic and political. To drive the economy of the metropolis, one of the way is through tourism (by 2016 the contribution of total travel and tourism to world GDP amounted to 7,613.3 million USD and rose in 2017 by $3.6 \%$ and is expected to continue to rise)(World Travel \& Tourism Council, n.d.). After searching for data by conducting surveys at several points and reviewing the literature, the theory of architourism in metropolis was used to help develop the economy of the city. But having a positive impact, tourism also has a negative influence on the metropolis that produces waste produced by tourists (USA TODAY, 2018). The solution that can solve this problem is to make space to educate the public and tourists on environmental issues, determine the use value of waste and then process the waste into something useful, making them spectacle and become interactive tool for tourists so it will be able to attract the attention of tourists but also can overcome the problem of waste that in the metropolis. The following solutions are combined into an exhibition space for recycling inorganic waste that can change the mindset of tourists who come about the ugliness of waste from an object that does not need to be value and use become an object that full of value and use.
\end{abstract}

Keywords: Architourism; Education; Metropolis; Tourism, Waste 


\section{PENDAHULUAN}

\section{Latar Belakang}

Metropolis merupakan kota yang memiliki peran penting dalam mengatur perekonomi dan politik daerah - daerah yang lebih kecil disekitarnya yaitu membantu dalam infrastruktur maupun ekonomi. Salah satu cara yang menjanjikan yaitu melalui pariwisata.

Akan tetapi pariwisata selain memiliki dampak positif juga memiliki dampak negatif terhadap metropolis. Salah satu dampak negatif nya yaitu banyaknya sampah yang di hasilkan dari wisata. Diantaranya yaitu penyebab kerusakan fasilitas umum, overcrowded, dan menimbulkan banyak sampah turis. Metropolis sendiri menghasilkan sangat banyak sampah per harinya, seperti Jakarta yang merupakan salah satu permasalahan yang paling umum ditemui (Prahadi, 2017) dan biasanya pihak pemerintah melakukan upaya untuk menyelesaikan permasalahan tersebut (contoh Jakarta memiliki PLTSA bantar gebang). Dari kasus tersebut wisata sejarah dan edukasi dapat menjadi salah satu wisata diruang metropolis terkait dengan sampah guna mengurangi dampak negatif dari turis sekaligus mengurangi permasalahan sampah dalam metropolis itu sendiri.

Permasalahan dan data menunjukkan perlunya sebuah sarana yang mampu menarik perhatian turis tetapi dapat meringankan permasalahan sampah yang ada di kota metropolis Jakarta. Solusi yang dapat menyelesaikan permasalahan tersebut adalah dengan dibuatnya sebuah ruang untuk mengedukasi masyarakat dan turis tentang pentingnya menjaga lingkungan dari sampah dan mengolah sampah- sampah tersebut menjadi sesuatu yang berguna dan menjadikan hal tersebut sebagai tontonan sehingga menarik.

\section{Rumusan Masalah}

1. Kurangnya kesadaran masyarakat dengan keadaan lingkungan terutama mengenai sampah sehingga perlu di tanamkan kesadaran akan lingkungan dengan membiasakan daur ulang sampah.

2. Peningkatan ekonomi metropolis dari sektor pariwisata memiliki dampak negatif salah satunya semakin banyak produksi sampah di metropolis. Bagaimana cara menangani atau seminimalnya mengurangi dampak sampah dari pariwisata?

\section{Batasan Masalah}

Proyek Ekshibisi Daur Ulang Sampah Anorganik berada di Kawasan Taman Mini Indonesia Indah dan berfokus pada daur ulang sampah anorganik di area sekitar perumahan dan perkantoran Taman Mini.

\section{Manfaat dan Tujuan}

Tujuan dari perancangan proyek ini yaitu menyediakan suatu ruang yang dapat mengedukasi orang-orang baik turis lokal, mancanegara maupun masyarakat sekitar untuk memiliki kebiasaan mendaur ulang sampah sehingga produksi sampah berkurang dan membantu mengurangi permasalahan sampah di kota Jakarta, kemudian menjadikan bangunan tersebut menjadi objek pariwisata sejarah dan edukasi.

\section{Sasaran Proyek}

Sasaran proyek Ekshibisi Daur Ulang Sampah Anorganik ini ditujukan untuk penduduk lokal maupun mancanegara serta merangkul komunitas pecinta sampah untuk terlibat dalam program bangunan Fasilitas Daur Ulang tersebut.

\section{METODE}

Mengambil data lapangan dengan survey langsung ke lokasi tapak yang terletak di Taman Mini Indonesia Indah dan survey ke tempat yang berhubungan dengan topik bahasan guna memperoleh data (Bank Sampah Jakarta). Mengambil data dengan wawancara dengan warga 
dan orang-orang yang berwenang guna memperoleh data. Mengambil data dari internet yang berupa wacana berita, artikel, buku referensi, dan jurnal ilmiah.

\section{DISKUSI DAN HASIL}

\section{Permasalahan}

Hampir semua jenis wisata dapat menjadi bagian dari ruang metropolis. Akan tetapi terdapat perbadaan wisata di metropolis dengan wisata diluar metropolis. Contohnya wisata ekologi yang mengambil tempat di hutan, gunung, maupun desa yang memberikan turis pengalaman merasakan keindahan alam dan kegiatan kegiatannya sebagian besar di lakukan di alam. Wisata ini mengandalkan hal-hal yang bersifat alami sebagai daya tarik wisatanya. Sementara wisata di metropolis cenderung tidak memiliki kekuatan daya tarik alam untuk menarik turis. Sebaliknya metropolis memiliki banyak amenitas yang tidak di miliki oleh wisata yang ada di desa, misalnya jalan yang lebih baik, akomodasi yang lebih baik, sanitasi yang lebih baik, dan bangunan-bangunan yang lebih baik. Wisata di metropolis mengandalkan kekuatan lingkungan yang di bangun oleh manusia sebagai daya tariknya salah satu nya dengan "Architourism". Architourism yaitu pariwisata yang menggunakan arsitektur sebagai daya tarik wisatanya.

Kemudian segala jenis pariwisata akan mengundang turis untuk berdatangan ke lokasi pariwisata tersebut termasuk pariwisata yang ada di metropolis. Padahal tanpa adanya turis, permasalahan di dalam metropolis seringkali tidak terpecahkan. Salah satu contoh permasalahan umum di kota Jakarta adalah permasalahan banyaknya sampah yang diproduksi sehari-hari. Jakarta memproduksi sekitar \pm 7000 ton sampah per hari (Komara, 2018). Sampah-sampah ini di kirim ke tempat penampungan akhir di TPST (Tempat Pembuangan Sampah Terpadu) Bantar Gebang. Bantar Gebang sendiri memiliki luasan 110 hektar dan di perkirakan mampu bertahan hingga tahun 2025 sehingga di perlukan bantuan proses penanganan sampah lain untuk memperpanjang umur TPST Bantar Gebang serta membantu mengurangi permasalahan sampah di kota Jakarta.

Setelah mengalisa permasalahan yang ada di metropolis dan menganalisa potensi pariwisata yang dapat menjadi salah satu bagian dari metropolis maka proyek yang di usulkan yaitu suatu wadah eksibisi daur ulang sampah anorganik yang dapat menjadi wisata sejarah dan edukasi bagi masyarakat, turis lokal maupun mancanegara. Misi dari bangunan ini adalah mengedukasi orang-orang dan menanamkan bahwa perlunya pemilahan sampah dan daur ulang sampah serta mengurangi jumlah pembuangan sampah ke Bantar Gebang. Program yang terdapat di dalam proyek yaitu:

\section{Galeri Sejarah Sampah}

Merupakan ruangan yang menyajikan perjalanan perkembangan sampah dan daur ulang hingga masa kini. Dilengkapi dengan ilustrasi lukisan, video, patung / miniatur, serta penjelasan mengenai sejarah perkembangan sampah dan daur ulang layaknya museum mini. Ruangan ini bertujuan pembuka untuk menyadarkan pentingnya daur ulang sampah dan mengajarkan bagaimana orang-orang perlahan sadar untuk mendaur ulang sampah demi lingkungan nya.

\section{Ruang Eksibisi Produk Daur Ulang (Kerajinan dan Seni)}

Ruangan ini merupakan ruangan untuk memamerkan hasil karya daur ulang sampah baik perabotan, karya seni, hingga produk hasil daur ulang sampah anorganik. Produk yang dipamerkan dapat dibeli sehingga orang menyadari sampah dapat menjadi sesuatu yang bernilai. Benda-benda yang dipamerkan di ruangan ini dapat berubah-berubah tergantung orang yang memamerkan karya nya di ruang ini baik seniman ataupun pengrajin. 


\section{Demo Room}

Setelah mengerti mengenai sejarah perkembangan dan daur ulang sampah, kemudian melihat bagaimana sampah menjadi sesuatu yang memiliki nilai orang-orang kemudian di masukkan ke suatu ruangan yang dapat membuat orang merasa tertekan atau jijik bagaikan dikelilingi sampah. Ruangan ini dimaksudkan untuk mendorong rasa ingin daur ulang kepada orang yang telah mengerti daur ulang dan melihat nilai dari sampah. setelah ditunjukkan ruangan yang orang-orang tertekan dan jijik selanjutnya dimasukkan ke ruangan yang bersih agar menyadari bagaimana dunia jika tanpa sampah.
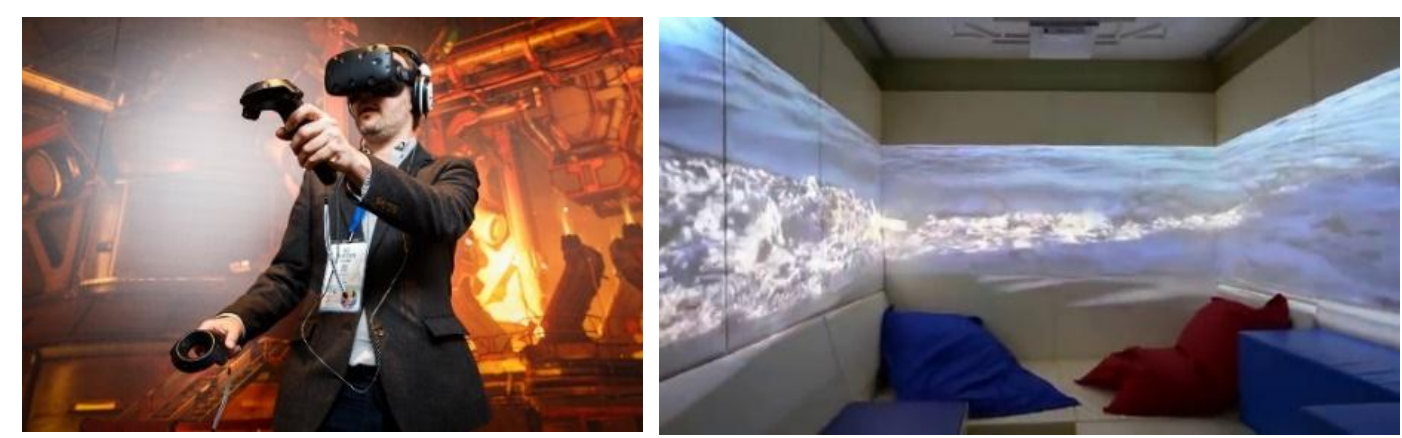

Gambar 1. Beberapa Contoh Demo Room Sumber: www.google.com

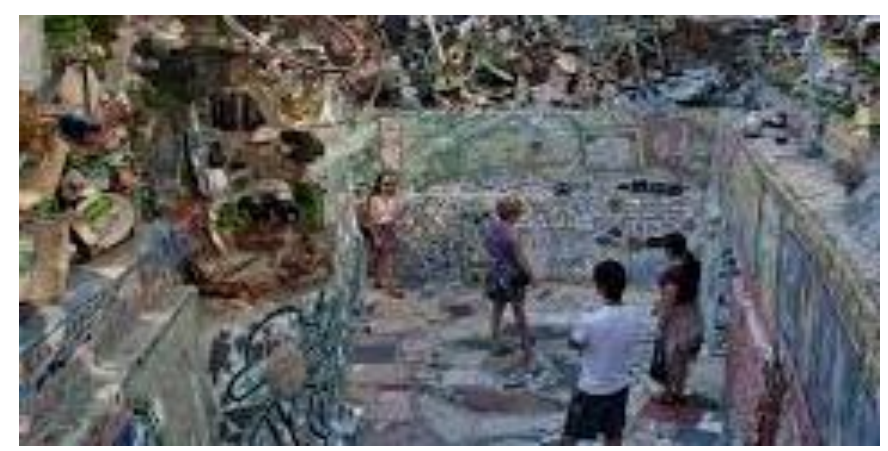

Gambar 2. Beberapa Contoh Demo Room Sumber: www.google.com

Untuk memanipulasi perasaan pengunjung di gunakan efek skala ruang dan juga efek warna pada ruangan untuk menciptakan kesan ruang yang dapat menekan pengunjung tetapi juga dapat menciptakan kesan ruang yang rapi dan bersih (14 warna primer, sekunder, tersier, dan netral).

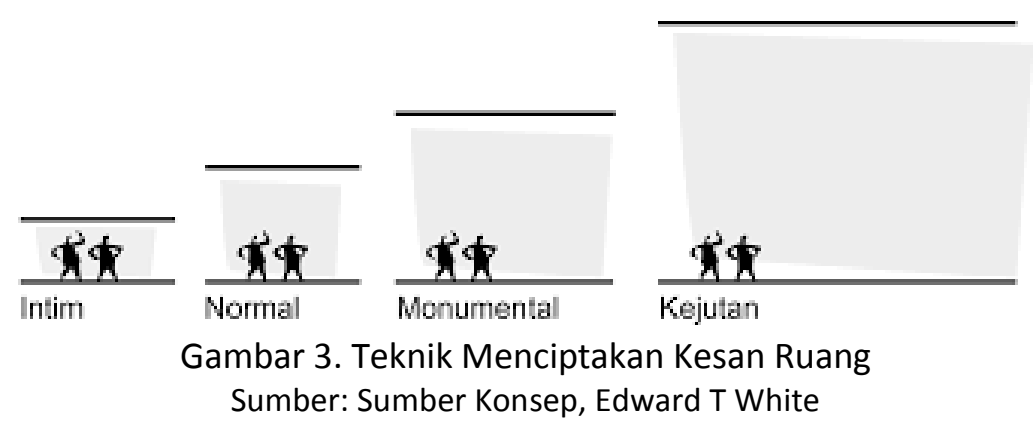

\section{Activity Room}

Di ruangan ini terdapat fasilitas untuk mencoba berbagai kegiatan yang berhubungan dengan daur ulang, misalnya mencoba mesin crane sampah mini, games, selfie spot, dll 


\section{Material Recovery Facility (MRF) Process}

Ruangan ini merupakan ruangan untuk mendaur ulang sampah anorganik menjadi bahan baku baru dan mengurangi pembuangan sampah ke TPA Bantar Gebang. Ruangan ini tidak dapat di akses oleh pengunjung akan tetapi pengunjung dapat melihat bagaimana proses pengolahan sampah dari datangnya sampah hingga menjadi benda lain yang akan didaur ulang dengan proses MRF.

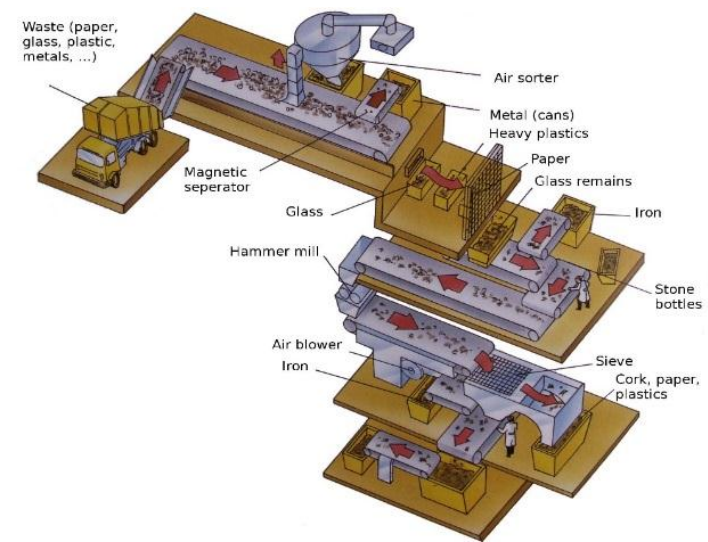

Gambar 4. Skema MRF

Sumber: https://en.wikipedia.org/wiki/Materials_recovery_facility

Jenis sampah yang dipilih yaitu sampah anorganik padat yang berasal dari rumah tangga dan perkantoran dan sampah jenis Large Waste dan Mining Wastes. Sampah-sampah tersebut yaitu:

1. Kaleng bekas

2. Botol bekas (kaca maupun plastik)

3. Kertas bekas \& plastik bekas

4. Tekstil

5. Bahan hancuran bangunan (pipa, batu bata, kayu, perabot bekas)

6. Mining wastes seperti bijih besi, logam

7. Ban bekas

Dari ke 7 daftar jenis sampah di atas, jenis benda yang akan di daur ulang yaitu :

1. Plastik dengan proses pencacahan akan diubah menjadi bahan baku biji plastik

2. Kertas dan alumunium akan dipisahkan dan dipadatkan untuk menjadi bahan baku kaleng dan kertas baru

3. Kayu akan diserut menjadi serbuk kayu

4. Kaca akan di ubah menjadi cullet

Jenis lainnya dapat digunakan dekorasi demo room, atau digunakan untuk kegiatan di dalam workshop, atau dipadatkan dengan compactor dan dikirim ke bantar gebang. jenis sampah ini dipilih karena sampah jenis ini tidak menghasilkan bau busuk seperti sampah organik, tidak mengandung bahan kimia berbahaya bagi orang yang bersentuhan, kemudian padat sehingga dapat di olah menjadi benda baru baik untuk kegiatan workshop dan suvenir, dan dikarenakan jenis sampah ini sulit terurai sehingga cara terbaik adalah dengan di daur ulang.

\section{Workshop}

Setelah melihat pentingnya daur ulang, kemudian didorong untuk mencapai lingkungan yang baik tanpa sampah, dan melihat proses daur ulang; ruangan ini merupakan tempat di adakannya kegiatan yang berhubungan dengan praktik daur ulang. Misalnya adanya kelaskelas bagaimana pemilahan sampah, kelas mendaur ulang sampah menjadi barang baru yang nantinya menjadi souvenir bagi pengunjung, dll. 


\section{Ruang Produksi Barang Daur Ulang dan Ruang Souvenir}

Ruang ini merupakan tempat dimana souvenir di produksi dengan bahan daur ulang menjadi produk baru yang utuh. Sebelumnya sampah diubah menjadi bahan baku pabrik untuk memperlihatkan bagaimana proses daur ulang berlangsung, maka di tempat ini diperlihatkan bagaimana mengubah sampah menjadi produk/benda baru yang dapat digunakan dalam kehidupan sehari-hari (Tas, Hiasan, Perabot, Mainan, Payung, dll).

Sarana Pendukung (Gudang, kantor, kantin, mushola, dII)

1. Jenis Sampah Yang di Daur Ulang

Sampah telah di bagi bagi berdasarkan tipe, sumber, bentuk, dan karakteristiknya.

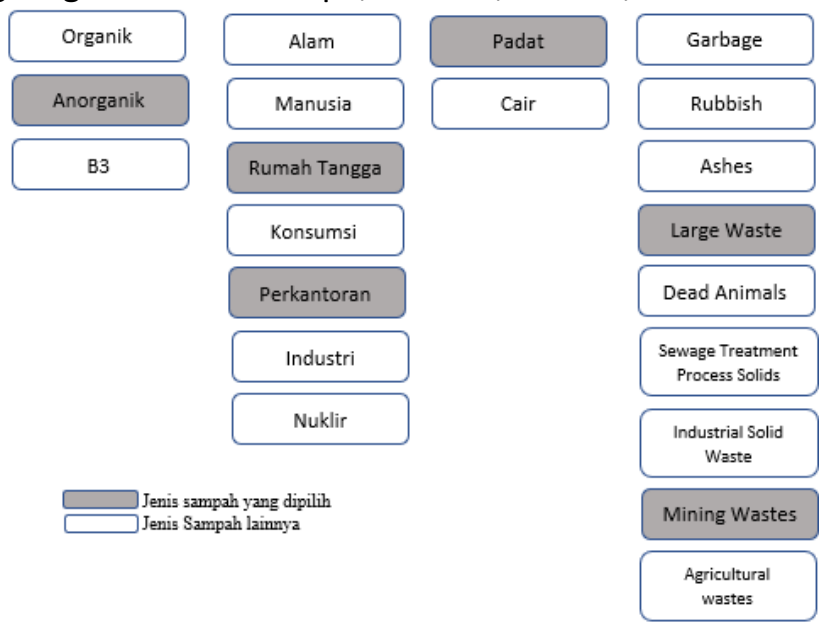

Gambar 5. Jenis SampahYang di Daur Ulang Sumber: Dokumentasi Pribadi

2. Hasil Daur Ulang Sampah Anorganik

Sampah anorganik merupakan sampah yang sulit terurai dan membutuhkan waktu yang lama untuk menguraikannya. Maka dari itu penanganan sampah anorganik berbeda dengan sampah organik yang dapat di urai dalam waktu yang relatif cepat. Salah satu penanganan sampah anorganik yaitu dengan daur ulang sehingga dapat dijadikan sesuatu yang memiliki nilai dan fungsi. Beberapa hasil daur ulang sampah anorganik di dalam proyek ini yaitu menjadi produk, karya seni, dan bahan baku kelas I untuk pabrik.

\section{Produk}

Sampah anorganik dapat didaur ulang menjadi benda sehari-hari oleh pengrajin sampah. Produk hasil daur ulang memiliki keunikan tersendiri.
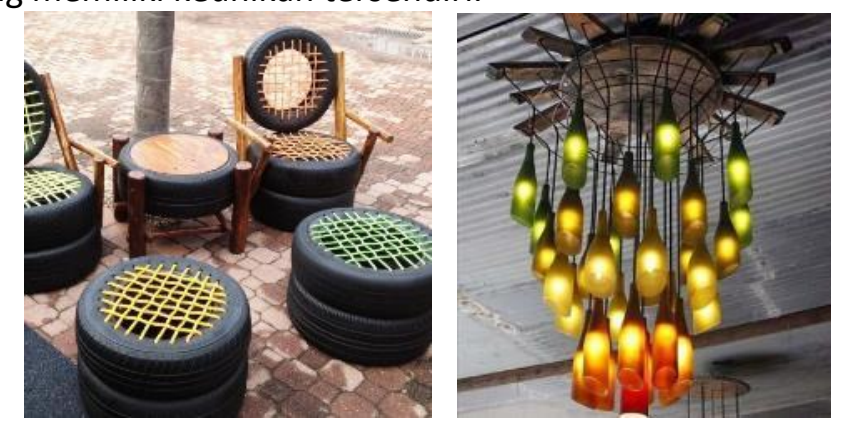

Gambar 6. Produk-Produk Hasil Daur Ulang Sampah Anorganik Sumber: www.google.com

4. Karya seni

Seorang seniman dapat menuangkan idenya di mana saja, dengan apa saja. Sampah pun 
menjadi salah satu media untuk menuangkan ide dan menunjukkan kreativitas seniman tersebut.
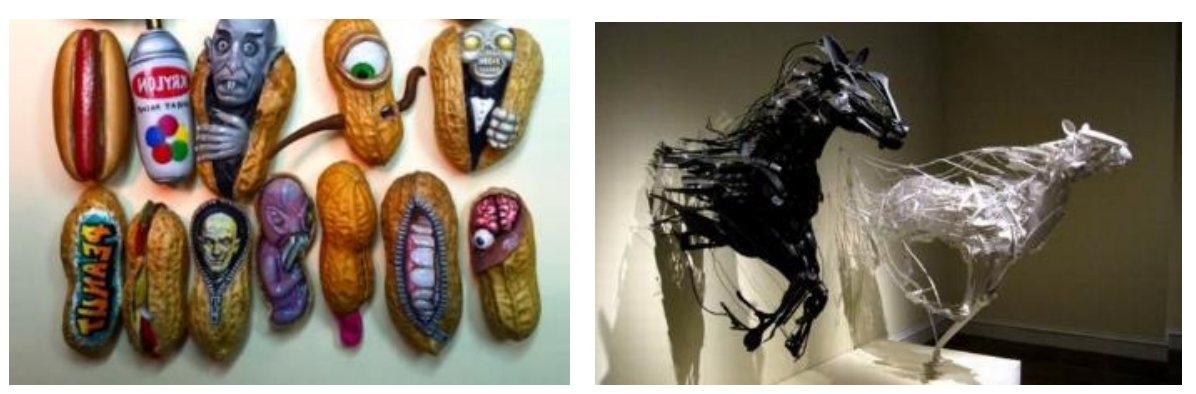

Gambar 7. Karya Seni Dari Sampah

Sumber: www.google.com

\section{Bahan baku}

Sampah anorganik juga dapat diubah menjadi bahan baku untuk pabrik. Misalnya logam dan plastik merupakan sampah anorganik yang jika di daur ulang menjadi benda baru maka kualitasnya tidak berkurang sama sekali. Kemudian kertas-kertas bekas dapat di daur ulang oleh pabrik menjadi buku dan kayu dapat di ubah menjadi serbuk kayu.
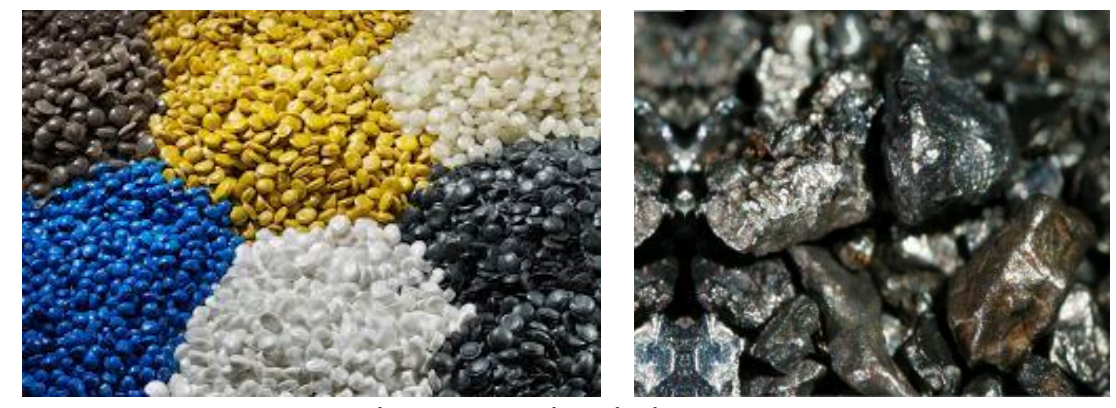

Gambar 8. Biji plastik dan Biji Baja

Sumber: www.google.com

a. Lokasi Proyek

Proyek ini berada di Jl. Taman Mini Indonesia Timur, Ceger, Cipayung, Jakarta Timur, Jakarta yang lebih tepatnya di dalam kompleks Taman Mini Indonesia Indah.

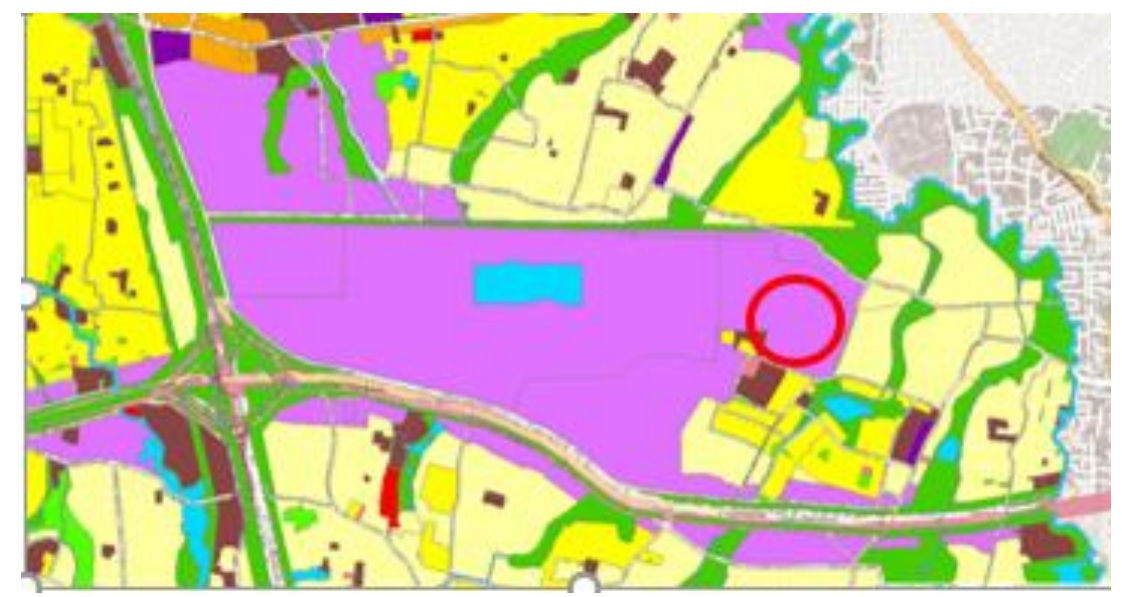

Gambar 9. Lokasi Proyek

Sumber: www.google.com

Kompleks Taman Mini Indonesia Indah sebagian besar sudah dipenuhi oleh berbagai wisata sejarah dan edukasi akan tetapi terdapat beberapa lahan kosong yang dapat di jadikan lokasi 
bangunan wisata dan edukasi yang melengkapi museum-museum di sebelahnya, tepatnya di seberang taman burung TMII. Terdapat area kosong yang berukuran $\pm 7.832 \mathrm{~m}^{2}$.

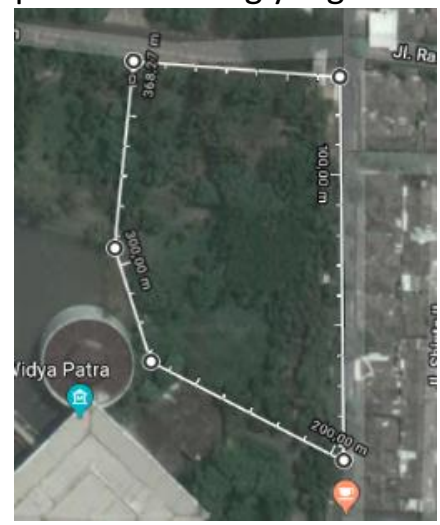

Gambar 10. Lokasi Proyek

Sumber: www.google.com

Taman Mini Indonesia Indah sendiri sudah di kenal sebagai salah satu destinasi wisata edukasi dan sejarah sehingga mampu menarik pengunjung lokal maupun mancanegara serta tata guna lahannya yang cocok dengan proyek fasilitas ekshibisi daur ulang sampah anorganik ini. Taman Mini Indonesia Indah memiliki wisata edukasi dan sejarah lainnya yang tersebar di seluruh area tapak. Hal ini memungkinkan turis untuk melakukan perjalanan ekskursi edukasi dan mencapai area eksibisi daur ulang sampah anorganik dalam satu perjalanan yang sama (One Stop Tour). Taman Mini Indonesia Indah telah menjadi salah satu area wisata Sejarah dan Edukasi terkemuka di ibukota sehingga hampir seluruh moda transportasi umum (Transjakarta, Angkutan Umum, LRT) yang melewati Taman Mini.

Faktor yang menjadi pertimbangan lainnya yaitu program yang terdapat di dalam bangunan yaitu memamerkan segala macam kegiatan yang mengandung sampah untuk di proses menjadi sesuatu yang baru, hiburan, dll. Program ini diharapkan akan membantu mengurangi jumlah sampah yang di kirim ke bantar gebang setiap harinya. Akan tetapi apapun program / proses untuk mereduksi jumlah sampah tetap akan menghasilkan limbah yang nantinya akan di kirimkan ke TPST Bantar Gebang. Dan tapak ini merupakan salah satu lokasi yang terdekat dari beberapa tapak lain menuju TPST Bantar Gebang.

b. Hasil Rancangan

Bangunan terdiri dari 3 lantai dan 1 basement untuk menampung segala program kegiatan yang telah direncanakan. Pembagian beberapa area dilakukan dengan perbedaan area di level tertentu. Level 1 memiliki Entrance, dan area yang berhubungan dengan ekshibisi produk ataupun galeri yang memerlukan loading dock. Di level ini terdapat basement yang merupakan area Material Recovery Facility kecil yang memamerkan proses daur ulang sampah anorganik menjadi bahan baku baru. Loading untuk area ini juga di lakukan di lantai 1 dengan shaft sampah. 


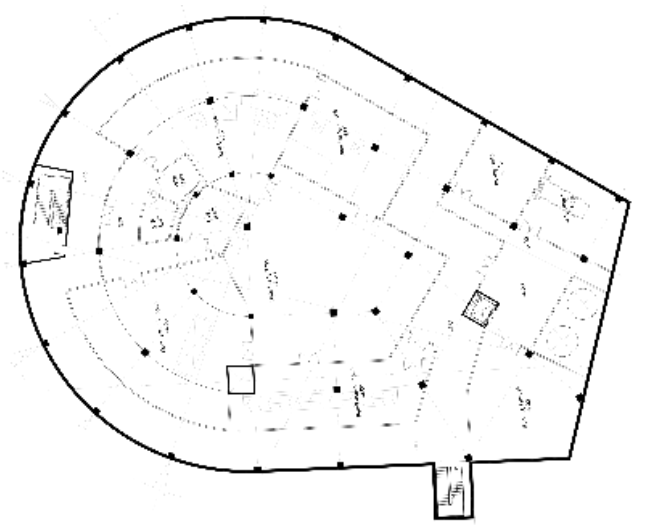

Gambar 11. Level Basement Sumber: Dokumentasi Pribadi

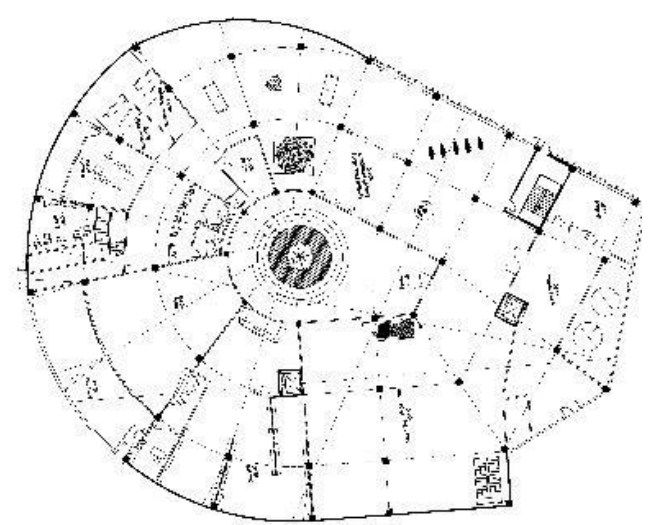

Gambar 12. Level 1

Sumber: Dokumentasi Pribadi

Kemudian level selanjutnya adalah area Demo Room yang menggunakan instalasi-instalasi alat peragaan untuk pengunjung.

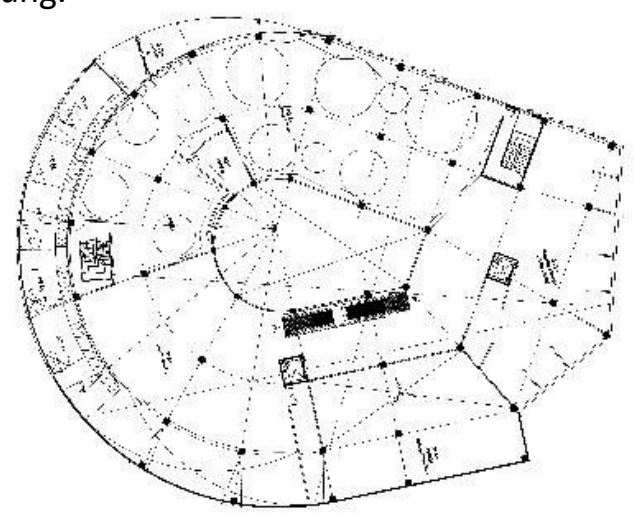

Gambar 13. Level 2

Sumber: Dokumentasi Pribadi 
Level mezzanine 2 sebagai Activity Room

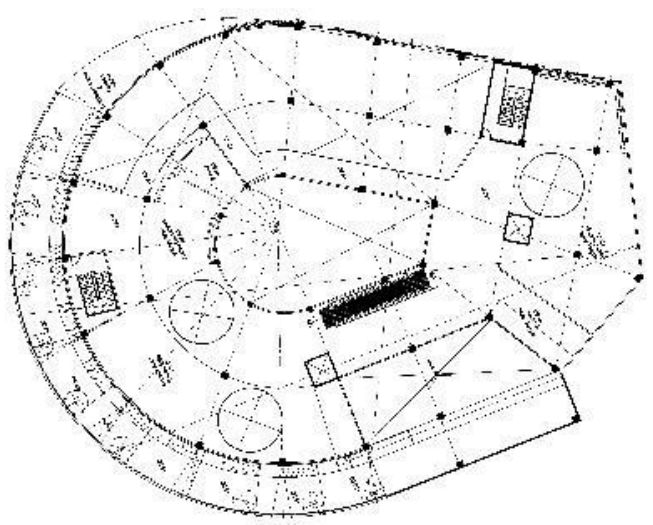

Gambar 14. Level Mezzanine 2

Sumber: Dokumentasi Pribadi

Lantai 3 sebagai area workshop sebelum akhirnya pengunjung di kirim kembali ke lantai 1 area souvenir dan pintu keluar bangunan.

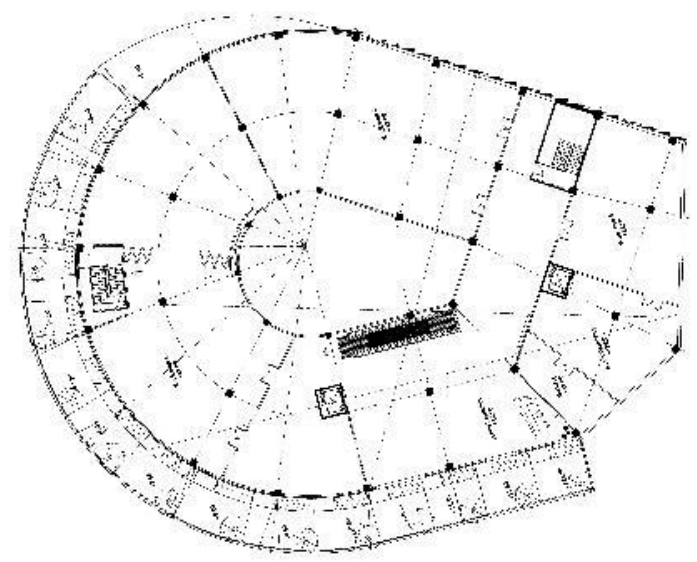

Gambar 15. Level 3

Sumber: Dokumentasi Pribadi

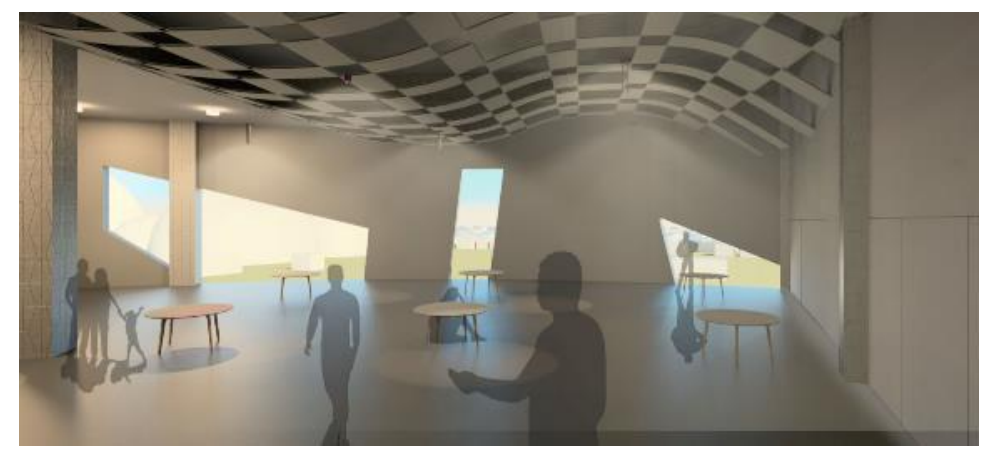

Gambar 16. Area Workshop

Sumber: Dokumentasi Pribadi

Bangunan mengandalkan void-void besar untuk menciptakan kesan luas, kemudian untuk membuat aktivitas-aktivitas yang berskala lebih besar, serta membuat ruangan terlihat lebih terbuka. 


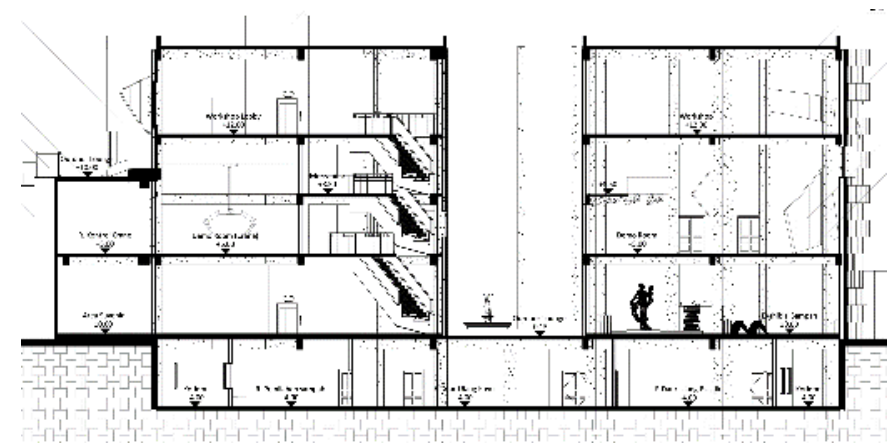

Gambar 17. Potongan Bangunan

Sumber: Dokumentasi Pribadi

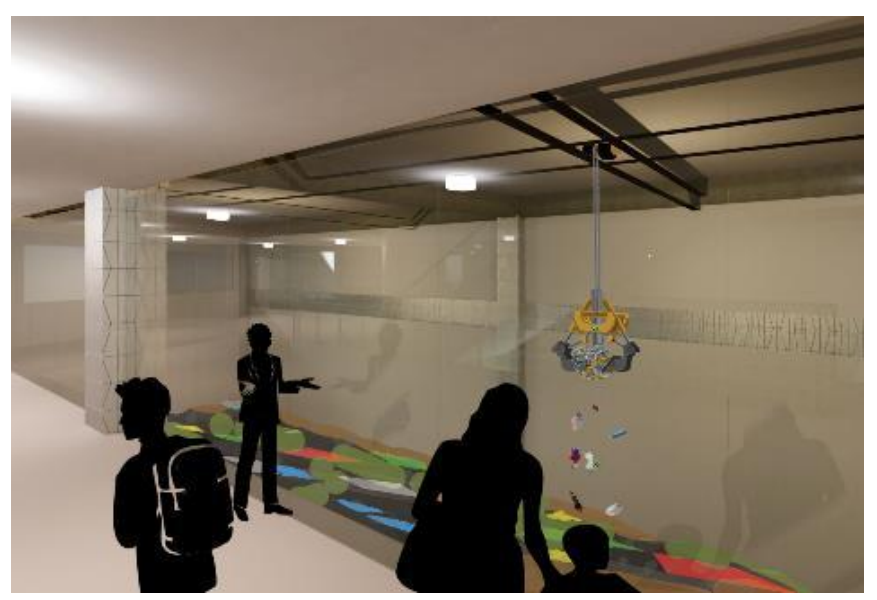

Gambar 18. Activity Room (Crane)

Sumber: Dokumentasi Pribadi

Pada bagian luar lantai 2 tardapat rooftop garden yang bertujuan untuk mengangkat level view serta memperbesar area hijau didalam tapak. Level view diangkat dikarenakan view dari bawah (Human Eye View) kurang menarik dan terhalang oleh banyak objek sehingga view kurang luas.

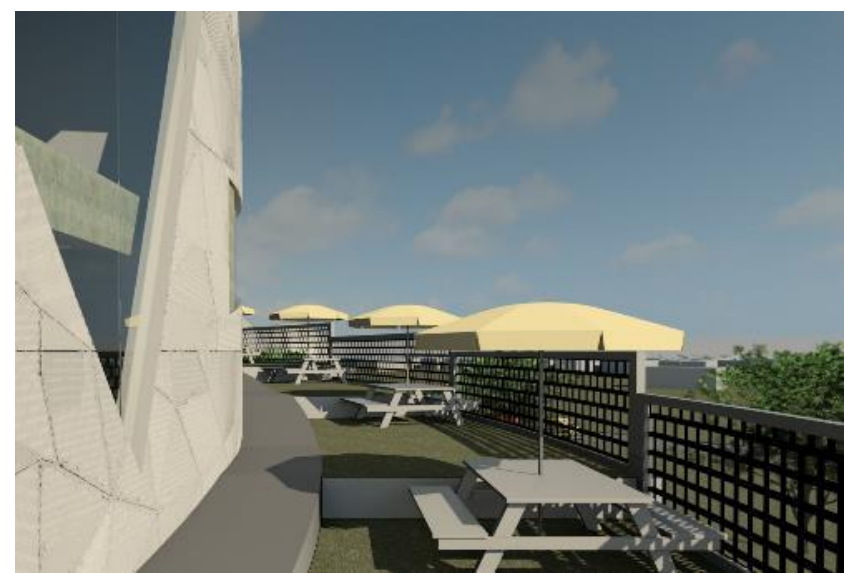

Gambar 19. Rooftop Garden

Sumber: Dokumentasi Pribadi 


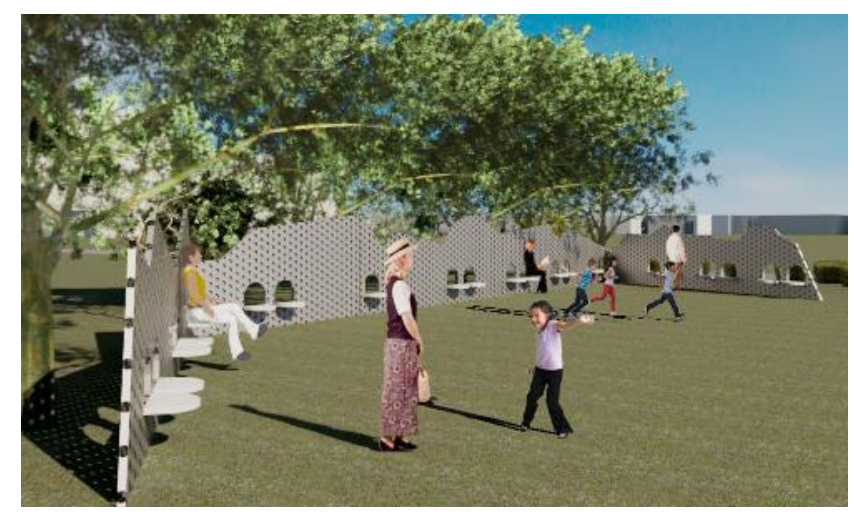

Gambar 20. Taman Ruang Luar

Sumber: Dokumentasi Pribadi

Dinding terluar bangunan menggunakan Fibre Cement yang di instalasikan di dinding bata. Fasad bertema daur ulang yang merupakan proses dari benda yang awalnya baik kemudian berubah menjadi sampah kemudian di olah kembali menjadi suatu benda baru yang berguna.

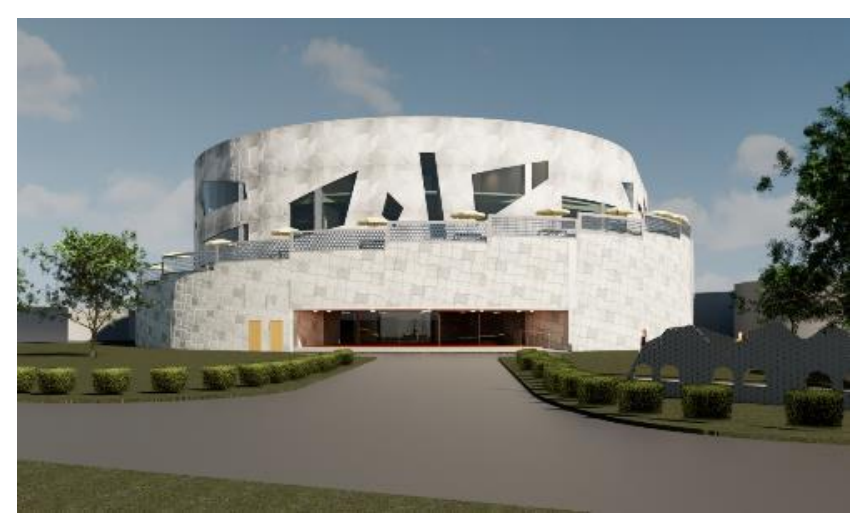

Gambar 21. Fasad Luar Bangunan

Sumber: Dokumentasi Pribadi

Jika bangunan di lihat dari sisi kiri ke kanan melambangkan benda yang baik lama kelamaan tidak terpakai, sebaliknya dari kiri ke kanan melambangkan sesuatu yang yang tidak terpakai menjadi sesuatu yang baru. Benda yang baru disimbolkan dengan papan-papan kayu yang disusun rapi kemudian perlahan menghilang digantikan dengan bukaan dan motif yang tidak beraturan sebagai simbol sampah atau benda yang rusak.

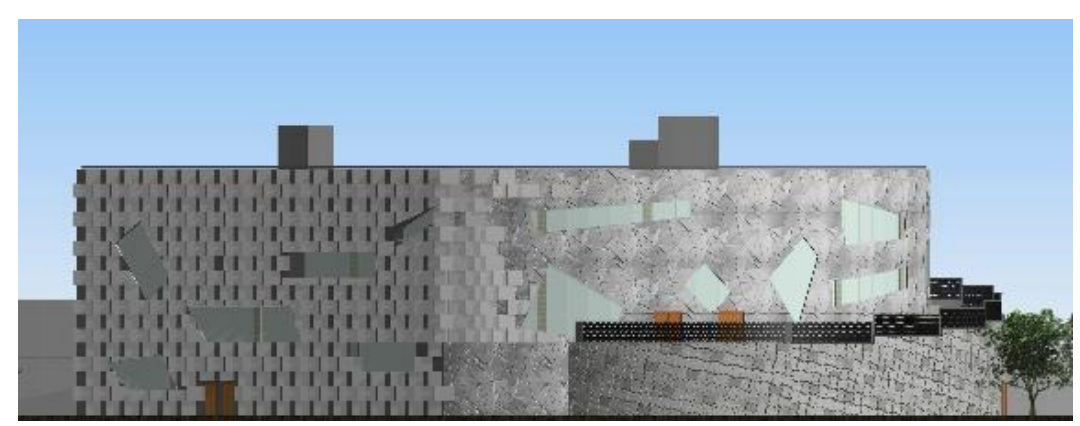

Gambar 22. Fasad Luar Bangunan

Sumber: Dokumentasi Pribadi 


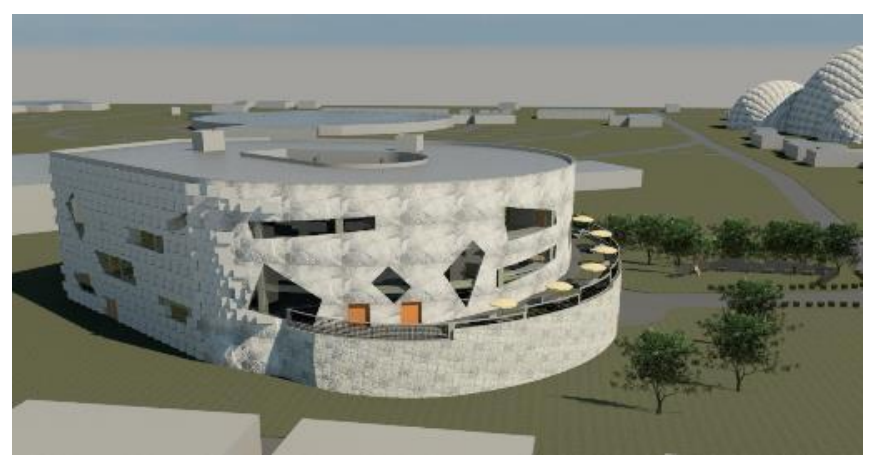

Gambar 23. Massa bangunan

Sumber: Dokumentasi Pribadi

\section{KESIMPULAN DAN SARAN}

Ekshibisi Daur Ulang Sampah Anorganik ini merupakan sebuah proyek yang bertujuan untuk memamerkan segala jenis kegiatan mengenai daur ulang, baik dari proses, hasil, nilainilai, serta pengetahuan mengenai sampah dan juga daur ulang. Berlokasi di Jakarta Timur (Taman Mini Indonesia Indah) yang menduduki posisi ke 3 dalam produksi sampah terbanyak di kota metropolis Jakarta. Proyek ini dapat membantu mengurangi jumlah sampah yang di kirimkan ke TPST Bantar Gebang sebanyak $\pm 5.5 \%$ sampah Anorganik dari Jakarta Timur. Angka ini terbilang kecil karena proyek ini memiliki fungsi utama sebagai area wisata sejarah dan edukasi. (mengurangi jumlah sampah hasil pariwisata adalah fungsi sekunder).

Fungsi Sejarah dan Edukasi yang hendak di capai dengan adanya Ekshibisi Daur Ulang Sampah Anorganik ini bukan berupa data / sejarah saja, melainkan menanam suatu sudut pandang baru kepada pengunjung Ekshibisi. Melihat suatu poin lebih dari sampah sehingga perlahan-lahan muncul keinginan dan menjadi kebiasaan untuk membuang sampah pada tempatnya dan memilah sampah untuk di daur ulang. Meskipun kecil dan perlahan-lahan dampaknya nantinya akan menolong permasalahan sampah di Metropolis dengan bangunan arsitektur yang mengedepankan Architourism.

\section{UCAPAN TERIMA KASIH}

Puji dan syukur penulis panjatkan kepada Tuhan Yang Maha Esa sehingga Jurnal Ilmiah yang berjudul "Ekshibisi Daur Ulang Sampah Anorganik" ini dapat selesai. Atas dukungan yang diberikan dalam penyusunan jurnal ini, maka penulis mengucapkan banyak terima kasih kepada para pembimbing yang memberikan masukan - masukan, ide-ide, saran serta memberikan dorongan kepada penulis; orangtua dan keluarga Penulis yang telah memberikan dukungan materiil maupun non-materiil dan doa sehingga Penulis dapat menyelesaikan jurnal ini dengan baik; teman dan sahabat Penulis di dalam maupun luar Universitas Tarumanagara yang telah mendukung dan membantu Penulis sehingga dapat menyelesaikan jurnal ilmiah ini.

Jurnal ilmiah ini belumlah sempurna, namun diharapkan jurnal ini dapat bermanfaat bagi orang-orang yang membacanya. Oleh karena itu, saran dan kritik dari semua pihak sangat dibutuhkan untuk penyempurnaan jurnal ini.

\section{REFERENSI}

Alex S. (2012). Sukses Mengolah Sampah Organik Menjadi Pupuk Organik. Yogyakarta: Pustaka Baru Press.

Azwar, Azrul. (1990). Pengantar Ilmu Kesehatan Lingkungan. Jakarta: Yayasan Mutiara.

Daniel, Valerina. (2009). Easy Green Living. Bandung: Hikmah.

Kaina. (2004). Color Theraphy : Pengaruh dan Kekuatan Warna Dalam Kehidupan. Jogjakarta: Enigma.

Kane, Anthony. (2015). Psychology 101: how to control, influence, manipulate, and persuade anyone. United States: Createspace Independent Publishing Platform. 
Kerrod, Robin. (1994). Energie en grondstoffen in de toekomst. Belgie : Artis-Historia.

Martin, Garry, Joseph Pear. (2003). Behavior Modification: What It Is and How to Do It. Seventh Edition. New Jersey: Prentice Hall. Inc.

Schiller, Jon, PhD. (2010). Global Change \& Energy Policy. Amerika: CREATESPACE.

Specht, Jan. (2014). Architectural Tourism. Germany: Springer Gabler.

White, Edward T. (1987). Sumber Konsep. Bandung: Intermatra . 